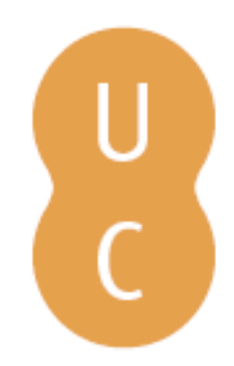

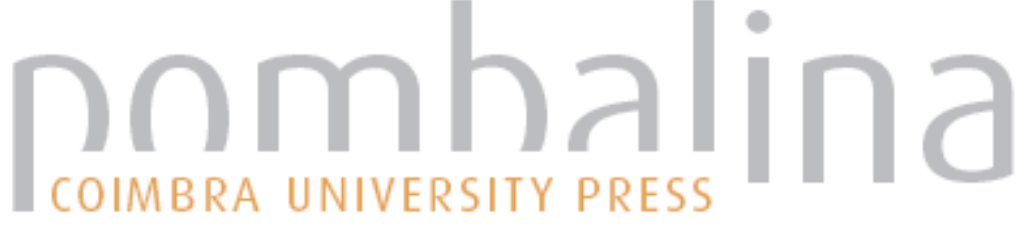

The influence of future time perspective in career decision-making: the mediating role of work hope
Autor(es):
Atanásio, Paula; Paixão, Maria Paula; Silva, José Tomás da
Publicado por: Imprensa da Universidade de Coimbra
URL
persistente:
URI:http://hdl.handle.net/10316.2/38624
DOI:
DOI:http://dx.doi.org/10.14195/978-989-26-0775-7_20
Accessed : $\quad$ 26-Apr-2023 12:09:55

A navegação consulta e descarregamento dos títulos inseridos nas Bibliotecas Digitais UC Digitalis, UC Pombalina e UC Impactum, pressupõem a aceitação plena e sem reservas dos Termos e Condições de Uso destas Bibliotecas Digitais, disponíveis em https://digitalis.uc.pt/pt-pt/termos.

Conforme exposto nos referidos Termos e Condições de Uso, o descarregamento de títulos de acesso restrito requer uma licença válida de autorização devendo o utilizador aceder ao(s) documento(s) a partir de um endereço de IP da instituição detentora da supramencionada licença.

Ao utilizador é apenas permitido o descarregamento para uso pessoal, pelo que o emprego do(s) título(s) descarregado(s) para outro fim, designadamente comercial, carece de autorização do respetivo autor ou editor da obra.

Na medida em que todas as obras da UC Digitalis se encontram protegidas pelo Código do Direito de Autor e Direitos Conexos e demais legislação aplicável, toda a cópia, parcial ou total, deste documento, nos casos em que é legalmente admitida, deverá conter ou fazer-se acompanhar por este aviso.

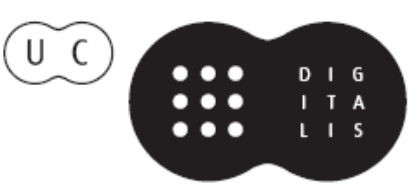




\section{INTERNATIONAL \\ STUDIES IN TIME \\ PERSPECTIVE}

MARIA PAULA PAIXÃO

JOSÉ TOMÁS DA SILVA

(COORD.)

VICTOR ORTUÑO

PEDRO CORDEIRO

(EDITORS)

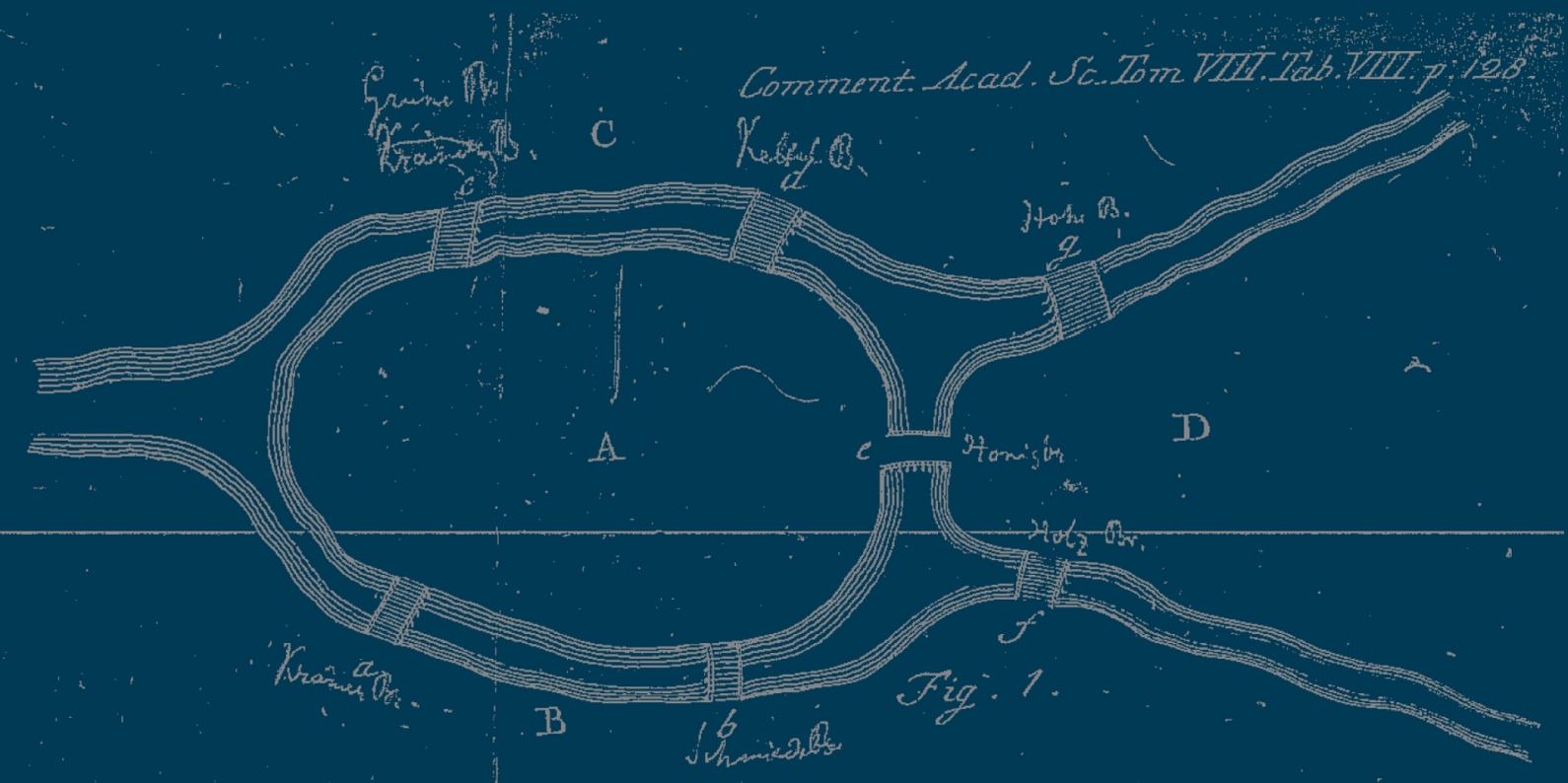

IMPRENSA DA

UNIVERSIDADE

DE COIMBRA

COIMBRA

UNIVERSITY

PRESS 


\title{
Chapter 20 \\ The influence of Future Time Perspective in Career decision-making: THE MEDIATING ROLE OF WORK HOPE
}

\author{
Paula Atanásio \\ paulatanasio@gmail.com \\ Maria Paula Paixão \\ mppaixao@fpce.uc.pt \\ José Tomás da Silva \\ jtsilva@fpce.uc.pt \\ Faculty of Psychology and Educational Sciences, University of Coimbra, Portugal
}

Aвstract: Career decision making (CDM) remains a core construct within Career Counseling research and practice. The notion of career implies a future time perspective (FTP), since future orientation is central to define vocational goals and therefore the pathways to achieve them. Complementarily, Work Hope (WH) is a psychological resource that implies goal-directed thinking, agency and pathways. However, little is known about the functional relationships between these variables, and the possible influence mechanisms of FTP and WH in CDM remains an understudied topic. The present study aims to (1) To analyze the relationship between FTP, WH and CDM; (2) to assess the mediation effect of WH in the relationship between FTP and adult CDM. Sample included 205 individuals attending adult education courses (age range: 18-61 years old; mean age: $M=37.01, S D=10.82$; gender: $54 \%$ male; low socio-economic background: $66.2 \%)$. Future Time Perspective Scale, Work Hope Scale, Career Indecision Scale, and a socio-demographic datasheet were administered to participants. Pearson correlation matrixes were obtained to examine the association between variables, and mediation effects were tested using the internet version of MedGraph-I (Jose, 2003). Moderate associations were observed between FTP and WH $(r=.30, p<.001)$, WH and CDM $(r=.46, p<.001)$, and FTP and CDM $(r=.21, p<.01)$. WH was found to mediate the relationship between FTP and CDM (Sobel $z=3.72, p<.001$; lower 95\% SCI .05 , upper 95\% SCI .15 ). Despite its cross-sectional design, and the likely mutual relationships between assessed variables, results from the present study suggest interesting functional hypotheses to be tested in future longitudinal studies. In the context of career counseling, interventions targeting FTP may positively impact CDM through the development of $\mathrm{WH}$ as psychological resource.

Keywords: future time perspective, work hope, career decision.

\section{INTRODUCTION}

Change is a hallmark of today's society. The changing patterns of work conditions and demands are quite distinct from those observed at the beginning of the $20^{\text {th }}$ century, and therefore, the context of decision making in general has dramatically changed. At the present moment, people are expected to make decisions in different moments and across a variety 
of contexts, within an overall framework of uncertainty and constant change. Since this is particularly the case for work contexts and related career decision requirements, career decision making (CDM) stands nowadays as a major core construct within Career Counseling. Although the importance of time perspective interventions has been acknowledged for assisting clients' decision making processes (Savickas, 1991), the determinant role of future time perspective (FTP) in CDM remains understudied. Moreover, little is known about the potential variables and mechanisms through which FTP may influence CDM. Research on these matters is greatly needed, because the empirical evidence derived from those studies would enable a better understanding of factors related to CDM and hence improve counseling interventions designed to promote adaptive career decisions.

During the last decades, different theoretical formulations have attempted to describe CDM processes, by systematically identifying difficulties related to career indecision (Gati, Krausz \& Osipow 1996). These theoretical proposals aimed at either prescribing how to make the best decision (normative or prescriptive models), or at understanding how people actually make decisions (descriptive models) (Germeijs \& De Boeck, 2002). Notwithstanding the definite relevance of these theoretical developments, the positive concept of "career decisiveness" may be seen as complementary to the more negative notion of "career indecision", and hence portray a broader picture of CDM processes and outcomes (Savickas, Carden, Toman \& Jarjoura, 1992). Career decisiveness is defined as "an individual's certainty about his/her career decision, where certainty relates to the extent an individual is convinced that he/she can make a career" (Osipow, Carney, Winer, Yanico, \& Koschier, 1987, cit in Pečjak \& Košir, 2007). Since people’s inability to think in terms of time perspective has been suggested as a good indicator of their career indecision level (Savickas, Silling, \& Schwartz, 1984), the study of the related concept of future time perspective (FTP) and its associations with career indecision and career decisiveness provides a promising research venue.

The notion of "career" intrinsically implies a FTP, since future orientation is central to defining vocational goals and therefore the pathways to achieve them (Marko \& Savickas, 1998). FTP can be defined as the individual's perception about his future (Husman \& Shell, 2008), and the anticipation of future goals in the present moment (Simons, Vansteenkiste, Lens \& Lacante, 2004). FTP is best conceptualized as a multidimensional phenomenon, encompassing four dimensions: "Value" (also termed as "Valence"), representing the valuing of the future and the willingness to make sacrifices in the present to support the future; "Connectedness", the perceived connection between present activities and future goals; "Extension", pointing to an individual's time horizon; and "Speed", relating to the speed at which individuals feel the passing of time. Recent research on the associations between FTP and CDM self-efficacy and indecision, revealed that individuals who understand the importance of the relation between present steps and future goals (i.e. who perceive increased instrumentality related to FTP), tend to have more confidence in their ability to make decisions, and thus experience less anxiety about choosing and committing to a career (Walker \& Tracey, 2012). Interestingly enough, these results were in line with previous reports of general time perspective as an important determinant of adolescent career decision making (Savickas et al., 1984).

Complementarily to the significance of FTP in CDM, Savickas (1990, p. 3) highlighted that a "hopeful temporal experience prompts the self-conscious awareness of a subjective career and engenders the planful attitudes and planning competencies that are critical to 
career decision making and adjustment". Within the context of career decision research, this important claim implicitly argues for the consideration of the positive concept of "hope", and more specifically, "work hope". Work hope (WH) may be assumed as a psychological resource and is defined as "a positive motivational state that is directed at work and workrelated goals and is composed of the presence of work-related goals and both the agency and the pathways for achieving those goals" (Juntunen Wettersten, 2006, p. 97).

Given the utility of mediation analyses for going beyond the merely descriptive relationships among variables (Preacher \& Hayes, 2004), as well as its pertinence for theory development and intervention refinement (Shrout $\&$ Bolger, 2002), the present study had two main objectives: first, to assess the relationships between FTP, WH and CDM (i.e. career decisiveness) in adult trainees; and second, to examine the mediating effect of WH in the association between FTP and career decisiveness. Following the available literature and empirical research, it was predicted that moderate positive associations would be verified for the correlations between FTP, WH and career decisiveness. Despite the fact that the mediating effect of WH was also examined, no specific predictions were made in that regard.

\section{Method}

\section{Participants}

The convenience sample for this study $(N=205)$ was recruited in an urban school located in the North region of Portugal, between February and May 2011. The following inclusion criteria were considered: a minimum age of 18 years old, and the attendance of an adult educational/training course. Two hundred and thirty-five subjects were then assigned to participate in the study, but only 220 were administered the research assessment protocol, since the remaining 15 subjects dropped out from the courses they were attending or were absent during the established periods for sample collection. After completion, 15 cases were further excluded: 7 cases did not complete all the intended measures, and 8 cases reported an updated professional status of "retired".

\section{Measures}

Career Indecision Scale (CIS) (Germeijs \& De Boeck, 2002). CIS is a measure used to assess career indecision. This scale was constructed based on the eleven descriptors for difficulties in making decisions, identified by Germeijis and De Boeck (2002) (e.g. taking a long time to decide; finding it difficult to make a decision). For each feature a positive item and a negative one was formulated, to counteract response tendencies (e.g.: "I find it easy to make this decision"/"It is hard for me to come to this decision"). The 22-item scale is to be scored in a 5-point Likert scale from 1 (Strongly disagree) to 5 (Strongly agree). Given the scope of the present study, which was mainly interested in examining the associations between WH and FTP (two "positive" constructs) and CDM, we opted to revert all negative items, in order to achieve a "positive" overall score that might be indicative of "career decisiveness" (as opposed to "career indecision"). Adequate scale internal consistency was verified within the study sample $(\alpha=.83)$. 
Work Hope Scale (WHS) (Juntunen \& Wettersten, 2006). The WHS assesses workrelated hope. The 24-item measure consists of three subscales: Agency (e.g. "I don't believe I will be able to find a job I enjoy"; "I doubt my ability to succeed at the things that are most"); Pathways (e.g. "I have a plan for getting or maintaining a good job or career"; "There are many ways to succeed at work") and Goals (e.g. "I expect to do what I really want to do at work"; "When I look into the future, I have a clear picture of what my work life will be like"). Participants were asked to indicate their level of agreement on the statements using a 5-point Likert scale from 1 (Strongly agree) to 5 (Strongly disagree). Total scores varied between 24 and 120, with higher scores indicating increased work hope. Good internal consistency values were found in our sample for the overall scale $(\alpha=.80)$.

Future Time Perspective Scale (FTPS) (Husman \& Shell, 2008). The FTPS is a selfreport measure to assess the individual's future time perspective, along its four dimensions: Value (7 items); Extension (5 items); Speed (3 items) and Connectedness (12 items). The FTPS comprises 27 items, to which respondents must indicate their agreement within a 5-point Likert scale ranging from 1 (Strongly disagree) to 5 (Strongly agree). Acceptable internal consistency values were observed in this study sample for the overall scale $(\alpha=.78)$.

\section{Procedure}

Authorization to collect data was obtained from the school's Direction Board. This school offered a variety of adult training/education courses, which were developed within the recent Portuguese political-educational initiative of "Novas Oportunidades" (literally: "New Opportunities"). Following an initial contact with the designated teacher, questionnaires were administered to trainees in the classroom, during the adult education sessions. Questionnaires took approximately 20 minutes to complete, under the supervision of the study's main researcher. Informed consents were obtained from all the subjects participating in the study, prior to their completion of the research assessment protocol.

\section{Data Analysis}

Descriptive statistics for socio-demographic variables were used to characterize the obtained sample. As regards the data from FTPS, WHS and CIS, missing values were replaced with item means. Internal consistency for the adopted measures was assessed through the calculation of their Cronbach's alphas, which were then classified as acceptable $(\geq .70)$ and optimal $(\geq .80)$ (Nunnally \& Bernstein, 1994). Pearson correlation matrixes were obtained to examine the association between variables, which were then classified as weak (.10 to .29), moderate (.30 to .49) or strong ( $\geq .50)$. For the examination of mediation effects, the online version of MedGraph-I (Jose, 2003) was chosen, because this online computational tool simultaneously provides information on the verified type of mediation (i.e. partial, full) and the underlying Sobel test, as well as providing a straight and clear graphical display on the observed mediation effects. Following Baron and Kenny's (1986) recommendations, three assumptions were to be met in order to detect a mediational effect: (1) there should be a significant relationship between the independent variable (i.e. the predictor) and the dependent variable (i.e. the criterion); (2) there should be a significant relationship between the independent variable and the mediating variable; 
(3) the mediator had to be a significant predictor of the outcome variable in an equation including both the mediator and the independent variable.

\section{Results}

\section{Sample Characteristics}

The obtained sample included 205 participants (54.4\% women) within an age range between 18 and 61 years old $(M=37.01, D P=10.82)$. The majority of participants (71.9\%) had completed the secondary level of school (between 9 and 12 years of school). In this sample, most of the cases were classified as pertaining to low/medium socioeconomic backgrounds (97.5\%), and $60.7 \%$ of the participants were employed, in contrast to $39.3 \%$ of unemployed participants (see Table 1).

Table 1 - Socio-demographic and educational characteristics of the sample

\begin{tabular}{|c|c|c|c|}
\hline & & $n$ & $\%$ \\
\hline \multirow[t]{5}{*}{ Age $(M / D P)=37.01 / 10.82$} & & & \\
\hline & $18-30$ years & 61 & 30.2 \\
\hline & $31-45$ years & 92 & 45.5 \\
\hline & +46 years & 49 & 24.3 \\
\hline & TOTAL & 202 & 100,0 \\
\hline \multirow[t]{4}{*}{ Gender } & & & \\
\hline & Male & 93 & 45.6 \\
\hline & Female & 111 & 54.4 \\
\hline & TOTAL & 204 & 100.0 \\
\hline \multirow[t]{5}{*}{ Socioeconomic Status (SES) } & & & \\
\hline & Low & 133 & 66.2 \\
\hline & Medium & 63 & 31.3 \\
\hline & High & 5 & 2.5 \\
\hline & TOTAL & 201 & 100.0 \\
\hline \multirow[t]{4}{*}{ Professional Status } & & & \\
\hline & Employed & 119 & 60.7 \\
\hline & Unemployed & 77 & 39.3 \\
\hline & TOTAL & 196 & 100.0 \\
\hline \multirow[t]{6}{*}{ Educational Level } & & & \\
\hline & $4^{\text {th }}$ grade & 8 & 3.9 \\
\hline & $6^{\text {th }}$ grade & 37 & 18.2 \\
\hline & $9^{\text {th }}$ grade & 146 & 71.9 \\
\hline & $12^{\text {th }}$ grade & 12 & 5.9 \\
\hline & TOTAL & 203 & 100.0 \\
\hline
\end{tabular}

Note. Socioeconomic status (SES) was determined using a classification system based on the individual's job and educational level (Simões, 1994). 


\section{Inter-correlations between the Variables}

Moderate associations were observed between FTP and WH $(r=.30, p<.001)$, WH and CDM-Career Decisiveness $(r=.46, p<.001)$, and weak between FTP and CDM-Career Decisiveness $(r=.21, p<.01)$.

\section{Mediational Analyses}

A mediator effect of WH was observed in the association between FTP and CDMCareer Decisiveness (Figure 1), since there was a significant drop in the coefficient for the relationship between FTP (independent variable/predictor) and CDM-Career Decisiveness (dependent variable/criterion), after the mediating variable (WH) was entered $(r=.21$, $p<.01$ to $r=.08, n s ;$ Sobel $z=3.72, p<.001$ ).

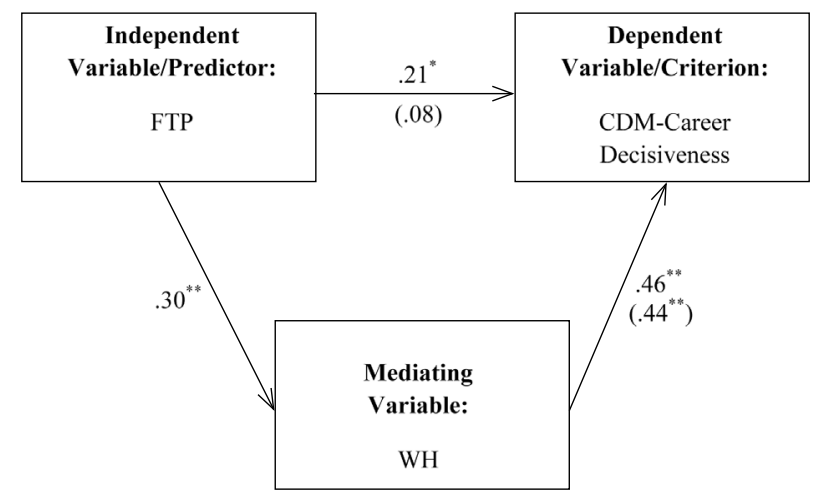

Note. ${ }^{* *} p<.001,{ }^{*} p<.01$

Figure 1. The mediating effect of WH on the link between FTP and CDM-Career Decisiveness.

\section{Discussion}

This study aimed at assessing the associations between FTP, WH and CDM (career decisiveness), and further examining the mediating role of $\mathrm{WH}$ on the relationship between FTP and CDM-Career Decisiveness. This study's findings confirmed our hypothesis that FTP, WH and CDM-Career Decisiveness were positively and moderately associated, apart from FTP and CDM with a weak association. This finding was in agreement with previous research on the associations between FTP and career decision variables (Walker \& Tracey, 2012) and added empirical support for the theoretical claim that hopeful temporal experience may play a determinant role in CDM (Savickas, 1990). Moreover, evidence was found for a mediator effect of WH, thus suggesting that an individual's FTP may be linked to his/her CDM-Career Decisiveness, through his/her perceptions of WH.

These findings suggest that interventions focusing on the development of the individual's FTP, may improve his/her CDM, while increasing his/her career decisiveness. Findings from this study also validated a potential mechanism via which FTP may exert 
its effects on CDM-Career Decisiveness, namely through perceived work hope. For this reason, interventions targeting FTP and aimed at improving CDM outcomes should incorporate measures on the construct of $\mathrm{WH}$, in order to effectively plan and monitor the intervention process.

This study had the merits of exploring patterns of associations between the more classical variables, such as career decisiveness, and the relatively more recent variables in Vocational Psychology, such as FTP and WH. Nevertheless, its cross-sectional design stands as it major limitation, since directionality cannot be inferred; in addition, caution must be taken in generalizing the observed results, since they were obtained from a sample with rather specific age, educational and professional characteristics.

Despite these limitations, this study's results offer promising insights that may be further examined in future longitudinal studies, possibly in other adult populations. In that sense, the utilization of more sophisticated statistical procedures, such as structural equation modeling and/or bootstrapping procedures, would be highly recommended as they currently represent analytical alternatives with the greatest statistical power. Finally, it would be interesting to test the plausible hypotheses that multiple variables may operate in the links between FTP and CDM, and that such indirect effects may operate distinctively for different groups; for these purposes, the so-called multiple mediation and moderated mediation analyses would be warranted.

\section{REFERENCES}

Baron, R. M., \& Kenny, D. A. (1986). The moderator-mediator variable distinction in social psychological research: Conceptual, strategic, and statistical considerations. Journal of Personality \& Social Psychology, 51, 1173-1182.

CoHen, J. (1988). Statistical power analysis for the behavioral sciences. Hillsdale, NJ: Erlbaum.

Gati, I., Krausz, M., \& Osipow, S. (1996). A taxonomy of difficultics incareer decision making. Journal of Counseling Psychology, 43, 510-526

Germeijs, V., \& De Boeck, P. D. (2002). A measurement scale for indecisiveness and its relationship to career indecision and other types of indecision. European Journal of Psychological Assessment, 18(2), 113-122. doi:10.1027//1015-5759.18.2.113

Husman, J., \& Shell, D. F. (2008). Beliefs and perceptions about the future: A measurement of future time perspective. Learning and Individual Differences, 18, 166-175. doi:10.1016/j. lindif.2007.08.001

Jose, P. E. (2003) MedGraph-I: A programme to graphically depict mediation among three variables: The internet version, version 2.0. Victoria University of Wellington, Wellington, New Zealand. Retrieved 2012 from http://www.victoria.ac.nz/staff/paul-jose-files/medgraph/medgraph.php

Juntunen, C. L., \& Wettersten, K. B. (2006). Work Hope : Development and initial validation of a measure. Journal of Counseling Psychology, 53(1), 94 -106. doi:10.1037/0022-0167.53.1.94

Marko, K. W., \& SaVICKas, M. L. (1998). Effectiveness of a career time perspective intervention. Journal of Vocational Behavior, 119(52), 106-119.

Nunnally, J., \& Bernstein, I. J. (1994). Psychometric theory (3 ${ }^{\text {rd }}$ ed). New York: McGraw-Hill.

PeČjaK, S., \& KošIr, K. (2007). Personality, motivational factors and difficulties in career decisionmaking in secondary school students. Psihologijske teme, 16, 141-158. 
Preacher, K. J., \& Hayes, A. F. (2004). SPSS and SAS procedures for estimating indirect effects in simple mediation models. Behavior Research Methods, Instruments and Computers, 36, 717-731. doi: 10.3758/BF03206553

SaviCKas, M. L. (1990, January). Career interventions that create hope. Paper presented at the Annual Meeting of the National Career Development Association, Scottsdale, AZ.

SAvickas, M. L. (1991). Improving career time perspective. In D. Brown \& L. Brooks (Eds.), Techniques of career counseling (pp.236-249). Boston: Allyn \& Bacon

Savickas, M. L., Silling, S. M., \& Schwartz, S. (1984). Time perspective in vocational maturity and career decision making. Journal of Vocational Behavior, 25, 258-269. doi:10.1016/00018791(84)90049-6.

Savickas, M. L., Carden, A. D., Toman, S., \& Jarjoura, D. (1992). Dimensions of career decidedness. Measurement and Evaluation in Counseling and Development, 25, 102-112.

Shrout, P. E., \& Bolger, N. (2002). Mediation in experimental and nonexperimental studies: New procedures and recommendations. Psychological Methods, 7, 422-445. doi: 10.1037//1082989X.7.4.422.

Simốes, M. (1994). Investigaçôes no âmbito da aferição nacional do teste das Matrizes Progressivas de Raven [Raven's Progressive Matrices: Standardization studies]. Unpublished Doctoral Dissertation. Universidade de Coimbra. Coimbra, Portugal.

Simons, J., Vansteenkiste, M., Lens, W., \& Lacante, M. (2004). Placing Motivation and Future Time Perspective Theory in a Temporal Perspective. Educational Psychology Review, 16(2), 121-139.

Walker, T. L., \& Tracey, T. J. G. (2012). The role of future time perspective in career decisionmaking, Journal of Vocational Behavior, 81(2), 150-158. doi: 10.1016/j.jvb.2012.06.002. 